\title{
Lima Bean Downy Mildew Epiphytotics Caused by New Physiological Races of Phytophthora phaseoli
}

\author{
C. R. Davidson, T. A. Evans, R. P. Mulrooney, N. F. Gregory, and R. B. Carroll, Department of Plant and Soil \\ Sciences, University of Delaware, Newark 19717; and N. R. O'Neill, United States Department of Agriculture, Sys- \\ tematic Mycology and Microbiology Laboratory, Beltsville, MD 20705
}

\begin{abstract}
Davidson, C .R., Evans, T. A., Mulrooney, R. P., Gregory, N. F., Carroll, R. B., and O’Neill, N. R. 2008. Lima bean downy mildew epiphytotics caused by new physiological races of Phytophthora phaseoli. Plant Dis. 92:670-674.

Before 1995, race D of Phytophthora phaseoli, the causal agent of downy mildew on lima bean (Phaseolus lunatus), was the prevalent physiological race in the mid-Atlantic region of the United States. Since 1995, however, new physiological races of $P$. phaseoli have been responsible for downy mildew outbreaks in previously resistant cultivars in this region. Cultivar differential testing of 180 isolates of $P$. phaseoli collected between 1994 and 2005 from Delaware and the eastern shore of Maryland has confirmed the presence of two new physiological races. The detection of race E in 1995 and race F only 5 years later in 2000, plus the lack of resistant cultivars to manage the epiphytotics in lima bean, have led to millions of dollars of crop losses. Intraand interspecific genetic variation of Phytophthora spp. and isolates were assessed using amplified fragment length polymorphism DNA fingerprinting. Primer groups EcoRI+AG and $M s e I+C$ distinguished $P$. phaseoli and $P$. capsici from $P$. infestans but did not distinguish among different races of $P$. phaseoli.
\end{abstract}

Since the nineteenth century, lima bean (Phaseolus lunatus L.) has been a commercial vegetable crop in the mid-Atlantic region of the United States (16). In 2002, Delaware harvested 6,880 ha of lima bean with a value of $\$ 5,647,000$ (21), making it one of the largest producers of lima bean in the United States. Lima bean crops are the cornerstone of the vegetableprocessing industry in Delaware and, without their profitable production, a number of other processing vegetable crops would not be grown in the region (17).

Downy mildew, caused by Phytophthora phaseoli Thaxt. (1889) (Oomycetes, Pythiales), is the most severe disease associated with lima bean production in Delaware and the mid-Atlantic region and the pathogen is only known to infect lima bean (9). Commercial yield loss due to downy mildew in 2000 was estimated to be $40 \%$, equal to a farm value loss of $\$ 3,000,000$ (E. Kee, personal communication). This pathogen is a fungus-like organism placed in the Kingdom Straminipila and infects

Corresponding author: T. A. Evans

E-mail: tomevans@udel.edu

Accepted for publication 15 December 2007.

doi:10.1094/PDIS-92-5-0670

(C) 2008 The American Phytopathological Society and colonizes flower racemes, shoot tips, and pods of lima bean, producing white downy mycelia and sporangia on shoot tips and pods; leaves are seldom affected (Fig. 1; 9,36). Under ideal environmental conditions for the pathogen, pods are covered with white, cottony mycelia growth with abundant sporangia. A reddish band usually surrounds the infected area and infected pods become necrotic, dried, and eventually shrivel. The disease is promoted by high relative humidity within the canopy $(5,11)$. Before 1995 , only four physiological races of $P$. phaseoli were known to exist (28). A physiological race, hereafter referred to as race, is defined as a subdivision of a pathogen species, particularly fungi, distinguished from other members of the species by specialization for pathogenicity in different host cultivars (18). Races have been identified using cultivar differentials as early as 1917 , when Stakman (25) began the development of his scheme for races of the wheat rust pathogen, Puccinia graminis f. sp. tritici Erikss. \& Henning $(23,24)$.

In 1889, Thaxter was the first to report Phytophthora phaseoli in lima bean in Connecticut (27), and the pathogen was found in lima bean in Delaware by Smith in 1903 (22). Until 1958, this race, later designated A (33), was the primary factor for lima bean production shifting from state to state in the eastern United States during the 1900s (12). In 1958, a second race of $P$. phaseoli, designated $\mathrm{B}$, was isolated from the lima bean cv. Thaxter in New Jersey (35). In 1969, a third race, designated $\mathrm{C}$, was isolated from the lima bean cv. Dover in New Jersey near the site of previous epidemics caused by race B (34). Race D of $P$. phaseoli was isolated first in 1975 from lima bean in experimental plots in Beltsville, MD (28) and in Delaware in 1990 (T. A. Evans, personal observation). Races A, B, C, and D of P. phaseoli, and the cultivars used to differentiate them, were clarified by Wester in 1970 (34), Thomas et al. in 1976 (28), Stavely in 1991 (26) and, Kee et al. in 1997 (17).

From 1990 to 1993 , race D was the only race of $P$. phaseoli detected in Delaware (T. A. Evans, unpublished). In 1995, three isolates of $P$. phaseoli from lima bean fields near Milton, DE, were determined to be different from race $\mathrm{D}$ in their ability to infect existing cultivar differentials and were designated race $\mathrm{E}$ (8). Six isolates of $P$. phaseoli collected in 2000 from lima bean fields near Milford and Frederica, DE, were determined by cultivar differentials to be a new race and were designated $F(8)$. The use of resistant cultivars remains the most cost-effective means of managing downy mildew of lima bean. The development of new races of $P$. phaseoli could result in major economic losses to lima bean growers and the vegetable-processing industry if breeders cannot develop resistant cultivars in a timely fashion.

A range of morphological and physiological criteria have been used to classify members of the genus Phytophthora. Molecular tools, particularly sequence analysis of the cytochrome oxidase I and II genes, have allowed for a comprehensive understanding of the phylogenetic relationships among species of this genus (19). However, subspecies-level differences generally are not resolved. DNA fingerprinting is a useful method for analyzing and revealing intra- and interspecific genetic variation within populations and among species of plant-pathogenic fungi, including Fusarium oxysporum (Sacc.) W.C. Snyder \& H.N. Hansen (1), Claviceps africana Freder., Mantle \& De Milliano (29), Ophiosphaerella agrostis Huds. (15), Sclerotinia ho- 
moeocarpa F.T. Benn. (31), and Colletotrichum spp. (20). Amplified fragment length polymorphism (AFLP) DNA fingerprinting analysis revealed the phylogenetic relationships of $P$. ramorum Werres, de Cock \& Man in't Veld to other species of Phytophthora (13), and the population structure of $P$. infestans (Mont.) de Bary (10). To identify and evaluate genetic diversity among isolates of $P$. phaseoli, genetic variation of 20 isolates of $P$. phaseoli representing different races was assessed by AFLP analysis and compared with that of $P$. capsici Leonian, a species closely related to $P$. phaseoli, and that of $P$. infestans.

Since the loss of cultivar resistance to the current races of $P$. phaseoli, fungicides have been needed, especially for control of downy mildew for lima bean cultivars without resistance to race F (9). Currently, several fungicides are labeled and effective for control of downy mildew if applied in a timely manner. Ridomil Gold/Copper (mefanoxam/copper), Phostrol (phosphorus acid salts), fixed-copper and Headline (pyraclostrobin) are currently labeled and effective. Fixed-copper fungicides currently available are good protectant fungicides when disease pressure is low to moderate, and they are good tank mix partners with mefanoxam and in rotation with other fungicides to prevent fungicide resistance. There is a high risk of fungicide resistance developing in Phytophthora spp. to mefanoxam. However, because few applications are made during the growing season and not all acres of baby lima bean are treated, the overall risk may be considered moderate for $P$. phaseoli; however, resistance to mefanoxam has been documented in P. phaseoli (R. P. Mulrooney, personal observation). Growers will use fixed coppers preventatively early in the fall when conditions become favorable for infection and will often switch to Ridomil Gold/Copper or Phostrol when downy mildew has been detected nearby or environmental conditions have been extremely favorable for infection. The objectives of this study were to (i) monitor the development of physiological races of $P$. phaseoli and the epiphytotics caused by them in lima bean in Delaware and the eastern shore of Maryland; (ii) determine the frequency of the various races of $P$. phaseoli yearly; (iii) characterize several races of $P$. phaseoli, $P$. capsici, and $P$. infestans for AFLP diversity; and (iv) develop a polymerase chain reaction (PCR)-based method for differentiating $P$. phaseoli from the closely related and lima bean pathogen, P. capsici.

\section{MATERIALS AND METHODS}

Isolations. From 1994 to 2005, lima bean fields in Delaware and the eastern shore of Maryland were scouted for the occurrence of downy mildew by Extension agents, commercial field scouts, university faculty, Extension specialists, and graduate students. Typical signs of downy mildew occur on maturing pods and appear as white, cottony mycelium with sporangia. Symptoms include a red border around the infected area of the pod and, later, shriveled, dry pods. Only infected, mature lima bean pods were collected. In 2000, home garden pole lima bean plants also were surveyed for downy mildew occurrence because it was believed that they might serve as a reservoir for older races of the pathogen. Home garden pole lima bean plants were not surveyed for downy mildew incidence in other years because the survey in 2000, a season with high inci- dence of downy mildew in production lima bean, resulted in only a few isolates. A minimum sample consisted of 5 to 10 infected pods. Pods were wrapped in dry paper towels and placed in plastic bags and delivered to the University of Delaware in Newark, usually within 3 days of collection. Isolations for $P$. phaseoli were made from the infected bean pods by plating on clarified lima bean pod agar (2) or rye isolating agar which was based on that of Caten el al. (4), with vancomycin at 100 $\mathrm{mg}$ liter $^{-1}$, ampicillin at $100 \mathrm{mg}$ liter $^{-1}$, polymixin b sulfate at $50 \mathrm{mg}$ liter $^{-1}$, and rifampicin at $50 \mathrm{mg} \mathrm{liter}^{-1}$. In some cases, isolations were made by first placing diseased pods between two layers of rye isolation medium. When fungal hyphae penetrated the layer of rye agar, hyphae were subcultured onto clarified lima bean pod agar or rye agar and maintained at 20 to $23^{\circ} \mathrm{C}$ in the dark.

Race identification. A methodology for the determination of races of $P$. phaseoli was adapted from the work of Wester (34), Thomas et al. (28), Stavely (26), and Kee et al. (17). New cultivars were added to the differentials cited above consistent with the development of new races of $P$. phaseoli in the period following the published cultivar differentials. The current set of differential cultivars of lima bean for determination of races of $P$. phaseoli can be found in Table 1 .

Table 1. Lima bean cultivars or lines used and their reactions to inoculation by isolates of Phytophthora phaseoli to differentiate physiological races

\begin{tabular}{lllllll}
\hline & \multicolumn{5}{c}{${\text { Races of } \boldsymbol{p}_{\text {phaseoli }}}^{\text {a }}$} \\
\cline { 2 - 6 } Cultivars, lines & A & B & C & D & E & F \\
\hline Early Thorogreen & R & S & S & S & S & S \\
Bridgeton & R & R & S & R & R & S \\
$8-78$ & R & R & R & R & S & R \\
$184-85$ & R & R & R & R & R & S \\
M-15 & R & R & R & R & S & R \\
BG2-408 & R & R & R & R & R & S
\end{tabular}

a Response of lima bean cultivars or lines to inoculation by isolates of races of $P$. phaseoli: $\mathrm{S}=$ susceptible, white downy mycelia and sporangia development on cotyledons and hypocotyls; $\mathrm{R}=$ resistant, lack of development of downy mycelia and sporangia on cotyledons and hypocotyls. Reactions for races $\mathrm{A}, \mathrm{B}$, and $\mathrm{C}$ are derived from the literature because isolates of these races were not available at the time of this research.
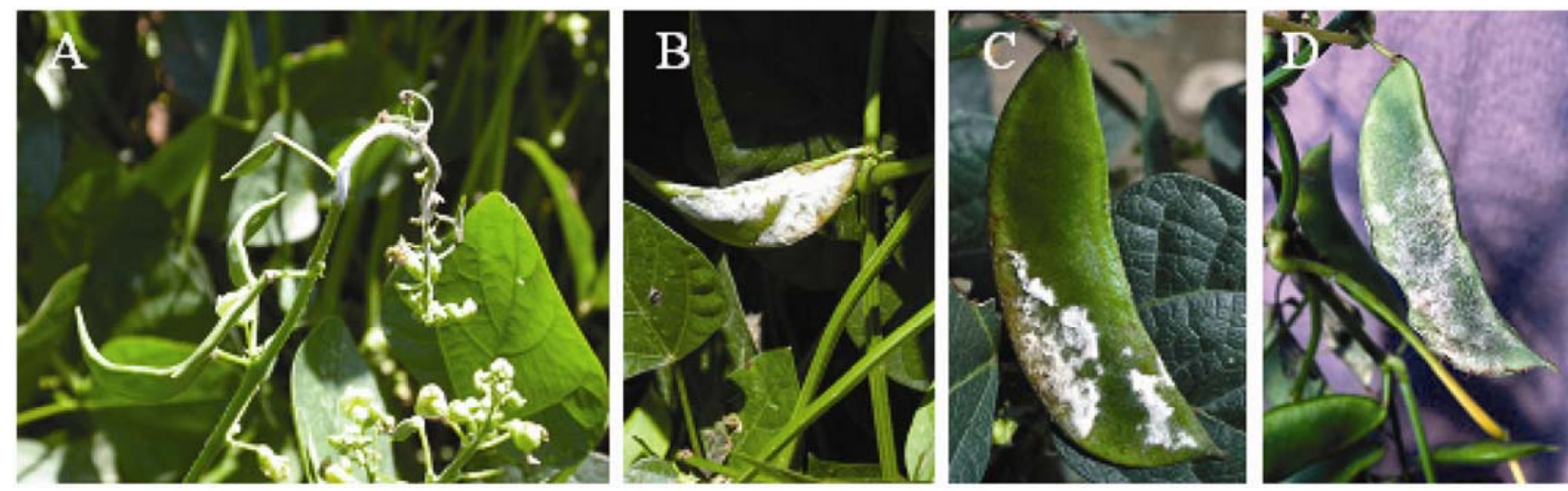

Fig. 1. Signs and symptoms of downy mildew of lima bean caused by Phytophthora phaseoli on A, flower racemes and $\mathbf{B}$, pods. Comparison of typical signs and symptoms of $\mathbf{C}$, P. phaseoli and $\mathbf{D}, P$. capsici. 
Race testing focused on distinguishing between isolates of race $D$, new races that may have developed, or older races that might become prevalent in the population of $P$. phaseoli in the region. Occurrence of races $\mathrm{A}, \mathrm{B}$, and $\mathrm{C}$ had not been reported since 1976 (28) and no isolates of these races were known to exist in 1994 when this work began. For race testing, five seeds were sown in 12.5-cm-diameter plastic pots containing Metro-Mix 510 (The Scotts Company, Marysville, $\mathrm{OH}$ ) and the pots were completely randomized and placed on heat mats in a greenhouse set at $25^{\circ} \mathrm{C}$ for germination. Replications were three pots per cultivar for each isolate.

Inoculum was produced by removing fungal growth of $P$. phaseoli from lima bean agar plates by gentle scraping with a sterile glass rod with the addition of $5 \mathrm{ml}$ of sterile distilled water. This slurry, con- taining sporangia and hyphal fragments from each plate, was added to separate flasks containing $295 \mathrm{ml}$ of sterile distilled water. The suspension was thoroughly mixed by hand shaking to free as many sporangia as possible and filtered through two layers of cheesecloth to remove agar debris, and the sporangia were enumerated with the aid of a light microscope. Hypocotyls typically emerged 5 days after seeding and each pot was inoculated with 100 $\mathrm{ml}$ of a suspension of $10^{3}$ sporangia/ml by pouring the slurry onto hypocotyls as they emerged from the soilless media. Hypocotyls typically are used to produce infected plants in vitro because they are susceptible and easy to manage in dew chambers, because of the small size of the plants at that time. In the field, hypocotyl infection has never been reported, likely because weather conditions are not condu-

Table 2. Yearly frequency of isolates of Phytophthora phaseoli, distinguished by race, from Delaware and Maryland lima bean samples collected between 1994 and 2005

\begin{tabular}{lllllll}
\hline & \multicolumn{5}{c}{ Yearly frequency of isolates collected within each race of P. phaseoli } \\
\cline { 2 - 7 } Year collected & A & B & C & D & E & F \\
\hline 1994 & 0 & 0 & 0 & 10 & 0 & 0 \\
1995 & 0 & 0 & 0 & 15 & 2 & 0 \\
1996 & 0 & 0 & 0 & 12 & 5 & 0 \\
1997 & 0 & 0 & 0 & 0 & 1 & 0 \\
1998 & 0 & 0 & 0 & 1 & 2 & 0 \\
1999 & 0 & 0 & 0 & 2 & 2 & 0 \\
2000 & 0 & 1 & 0 & 3 & 107 & 6 \\
2001 & 0 & 0 & 0 & 0 & 0 & 0 \\
2002 & 0 & 0 & 0 & 0 & 0 & 0 \\
2003 & 0 & 0 & 0 & 0 & 2 & 6 \\
2004 & 0 & 0 & 0 & 0 & 0 & 4 \\
2005 & 0 & 0 & 0 & 0 & 0 & 0 \\
\hline
\end{tabular}

${ }^{a}$ Races determined by inoculation of cultivars differentials as indicated in Table 1 . cive. Plants were maintained in a dew chamber at $75 \%$ relative humidity between 20 and $25^{\circ} \mathrm{C}$ for 10 days with 12 -h photoperiods at $75 \mu$ moles $\mathrm{m}^{-2} \mathrm{~s}^{-1}$. Isolates were rated for their ability to infect the cultivars 4 to 7 days after inoculation. Susceptibility was determined by the presence of white downy mycelia and sporangia developing on hypocotyls. Plants in individual pots were rated susceptible when a minimum of three seedlings exhibited typical signs of infection, as indicated by sporangial development on hypocotyls. Individual pots were rated resistant when all seedlings remained healthy.

AFLP DNA fingerprinting. Genetic variation of fungal isolates of $P$. phaseoli and their similarity to other related members of the Oomycota was examined. Twenty isolates of $P$. phaseoli representing races $\mathrm{D}, \mathrm{E}$, and $\mathrm{F}$; one isolate each of $P$. infestans mating types U.S.-1 and U.S.-8; and one isolate of $P$. capsici, recently identified as a pathogen of lima bean in Delaware (6) producing similar signs and symptoms (Fig. 1), were tested. Singlesporangial isolates were obtained from pure cultures of each isolate by serial dilutions (30) and plating on rye agar. Cultures were incubated at $20^{\circ} \mathrm{C}$ for 10 days with 12-h photoperiods until single colonies were observed, then subcultured on rye or clarified lima bean pod agar and grown under the same conditions until colonies grew to near the edge of the medium. All sporangial suspensions were prepared at the same time by adding $1 \mathrm{ml}$ of a sporangial suspension prepared with a sterile glass rod and $5 \mathrm{ml}$ of sterile distilled water to $200 \mathrm{ml}$ of clarified lima bean broth

Table 3. Isolates of Phytophthora phaseoli, P. infestans, and P. capsici used in amplified fragment length polymorphism analysis

\begin{tabular}{|c|c|c|c|c|c|}
\hline Accession no. & Phytophthora sp., lima bean cultivar source & Location of collection & Contributor & Year & Race \\
\hline 1 & P. infestans US- $1^{\mathrm{a}}$ & Beltsville, MD & Deahl & 2000 & $\ldots$ \\
\hline 2 & $P$. infestans US- $8^{\mathrm{a}}$ & Beltsville, MD & Deahl & 2000 & $\ldots$ \\
\hline 3 & P. capsici $^{\mathrm{b}}$, C-elite Select & Viola, DE & McConnell & 2000 & $\cdots$ \\
\hline 4 & P. capsici $^{\mathrm{b}}, 184-85$ & Preston, MD & Bagus & 2000 & $\ldots$ \\
\hline 5 & P. phaseoli, Pole Lima Bean & Middletown, DE & Evans & 2000 & B \\
\hline 6 & P. phaseoli, Unknown & Beltsville, MD & Tooley & 1999 & $\ldots{ }^{c}$ \\
\hline 7 & P. phaseoli, Packer & Milton, DE & Evans & 1998 & $\mathrm{D}$ \\
\hline 8 & P. phaseoli, Jackson Wonder & Preston, MD & Bagus & 1999 & $\mathrm{D}$ \\
\hline 9 & P. phaseoli, Butter Bean & Preston, MD & Davidson & 1999 & $\mathrm{D}$ \\
\hline 10 & P. phaseoli, M-15 DM11.EA.1 & Milford, DE & Davidson & 2000 & $\mathrm{~F}$ \\
\hline 11 & P. phaseoli, C-elite Select & Frederica, DE & Davidson & 2000 & $\mathrm{~F}$ \\
\hline 12 & P. phaseoli, Packer & Milton, DE & Evans & 1998 & $\mathrm{E}$ \\
\hline 13 & P. phaseoli, 5-85 & Milton, DE & Evans & 1998 & E \\
\hline 14 & P. phaseoli, M-15 & Milford, DE & McGowan & 1999 & $\mathrm{E}$ \\
\hline 15 & P. phaseoli, M-15 & Milford, DE & McGowan & 1999 & E \\
\hline 16 & P. phaseoli, Pole Lima Bean & Leipsic, DE & Mulrooney & 2000 & $\ldots^{\mathrm{c}}$ \\
\hline 17 & P. phaseoli, Pole Lima Bean & Marydel, MD & Davidson & 2000 & E \\
\hline 18 & P. phaseoli, Pole Lima Bean & Newark, DE & Carroll & 2000 & E \\
\hline 19 & P. phaseoli, Fordhook 1072 & Georgetown, DE & Kee & 2000 & $\mathrm{E}$ \\
\hline 20 & P. phaseoli, Jackson Wonder & Ruthsburgh, MD & Bagus & 2000 & E \\
\hline 21 & P. phaseoli, Jackson Wonder & Milford, DE & Wright & 2000 & $\mathrm{E}$ \\
\hline 22 & P. phaseoli, Eastland & Argo's Corner, DE & McGowan & 2000 & E \\
\hline 23 & P. phaseoli, 8-78 & Harrington, DE & Johnston & 2000 & E \\
\hline 24 & P. phaseoli, Packer & Milford, DE & McConnell & 2000 & E \\
\hline 25 & P. phaseoli, M-15 & Wyoming, DE & Mulrooney & 2000 & E \\
\hline
\end{tabular}

a Mating type for isolates of $P$. infestans.

${ }^{\mathrm{b}}$ Mating type for isolates of $P$. capsici not determined.

c Isolate later was determined to be contaminated. 
Cultures were incubated on an orbital shaker (Thermolyne, Dubuque, IA) at $20^{\circ} \mathrm{C}$ for 3 weeks with 12 -h photoperiods. Mycelia were collected by vacuum filtration from the broth, and DNA was extracted and purified as described in the DNeasy Plant Mini Kit (Qiagen, Inc., Valencia, CA). Once the DNA extractions were completed, they were examined by agarose gel electrophoresis and visualized by ethidium bromide staining. AFLP assays were performed with AFLP Analysis System I (Life Technologies, Inc., Gaithersburg, MD) with modifications $(14,20,32)$. Extracted genomic DNA was digested with EcoRI and MseI, ligated to adapters of known sequence containing oligonucleotide restricted fragments, and amplified by PCR. A preselective amplication PCR was performed followed by selective amplification using primers containing the common adaptor and restriction endonuclease recognition sequences plus one to two arbitrary nucleotides to select only a fraction of the restriction fragments. In preliminary experiments, 16 different primer combinations were evaluated (including AG, AT, and TA) in combination with EcoRI but observed levels of polymorphism among isolates were very low. EcoRI+AG combined with $M s e \mathrm{I}+\mathrm{C}$ was selected for further use. The PCR products $(2.5 \mu \mathrm{l})$ were separated by electrophoresis through a $6 \%$ (wt/vol) denaturing polyacrylamide gel containing $7.5 \mathrm{M}$ urea. Autoradiographs of the dried gels were obtained by exposing them to Kodak BioMax MR-2 film (Kodak Molecular Imaging Systems, New Haven, CT) for $3 \mathrm{~h}$ at $20^{\circ} \mathrm{C}$. Each lane of the autoradiograph was scored for the presence or absence of bands using Proscore (version 2.39; DNA ProScan Inc., Nashville, TN). The resulting binary matrices were analyzed to obtain simple-matching coefficients among the isolates using NTSYS-pc (version 2.0; Exeter Software, Setauken, NY). Simple matching coefficients were clustered to generate similarity trees using SAHN clustering using the unweighted pair-group method with arithmetic average (UPGMA) algorithm in NTSYS-pc (3).

\section{RESULTS}

Isolates. From 1994 through 2005, 180 isolates were collected from 101 lima bean fields in Delaware and the eastern shore of Maryland. During 2000 alone, 122 isolates were collected from 52 fields.

Race identification. Results of race identification for individual isolates collected from 1994 through 2005 are shown in Table 2. Ten isolates of $P$. phaseoli collected in 1994 from 10 lima bean fields in Delaware were race $\mathrm{D}$, the only race of $P$. phaseoli collected in that year. In 1995, 15 isolates of $P$. phaseoli collected from Delaware and Maryland were race D. Two isolates of $P$. phaseoli from two separate fields near Milton, DE, that were different from race $\mathrm{D}$ in their cultivar differentials reaction were designated race $\mathrm{E}(8)$.

During September 2000, a hurricane and additional ideal environmental conditions for the development of downy mildew resulted in a widespread epiphytotic in the mid-Atlantic region (Table 2). In that year, 107 isolates of $P$. phaseoli were collected from 52 lima bean fields in Delaware and the eastern shore of Maryland and were determined to be race E. Additionally, six isolates of $P$. phaseoli collected from six lima bean fields near Milford and Frederica, DE were unique in cultivar differentials response and were designated $\mathrm{F}$, a new race (8). In that same year, two isolates of $P$. phaseoli (Table 3, isolate 5 and
16) from a sample collected from a home garden pole lima bean near Middletown and Leipsic, respectively, initially were determined to be race $\mathrm{B}$. Isolate 16 later was determined to be a mixture of races and was not used in the AFLP analysis.

In 2001 and 2002, no occurrences of downy mildew were reported in Delaware or the eastern shore of Maryland (Table 2). In September 2003, environmental conditions similar to those in 2000, including a hurricane, led to minor outbreaks of downy mildew in eight lima bean fields in Delaware and Maryland. Of the eight isolates collected in that year, two were race $\mathrm{E}$ and six were race F. In 2004, only four isolates of $P$. phaseoli were collected, and all were

\section{SIMILARITY}

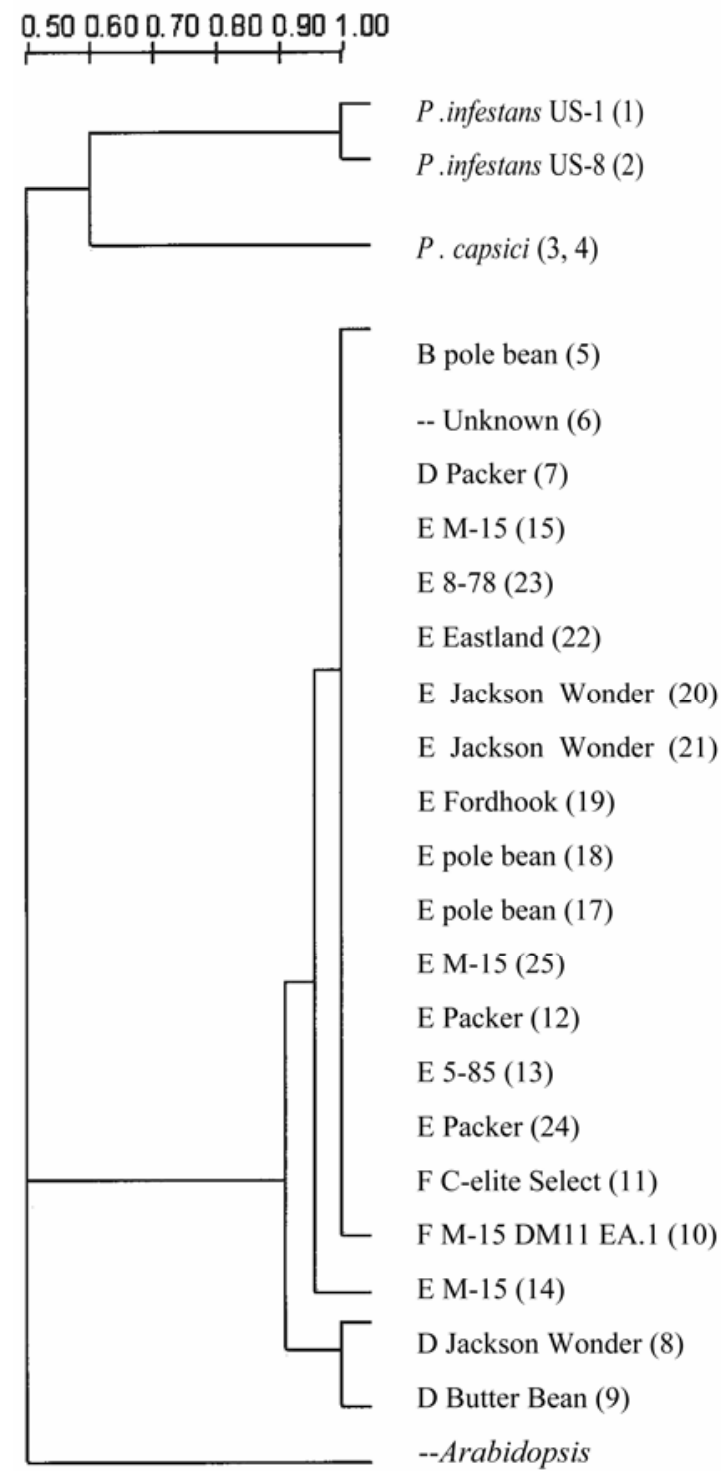

Fig. 2. Dendrogram showing similarities among 20 isolates of Phytophthora phaseoli and 2 isolates each of $P$. infestans and $P$. capsici based on amplified fragment length polymorphism analysis using simple matching coefficients. Number in parentheses indicates accession number of isolate from Table 3. The tree was generated using the SAHN clustering program with the unweighted pair-group method with arithmetic average algorithm in NTSYS-pc. Polymerase chain reaction products between molecular sizes of 80 and 212 bp were scored for the analysis. Similarity within P. phaseoli was $100 \%$ and between Phytophthora spp. was 50\%. Accession number 16 was omitted from the study due to sample contamination. 
race $\mathrm{F}$. There was only one confirmed occurrence of downy mildew in 2005. The organism infecting this lima bean pod sample was identified as $P$. phaseoli by determining the average length and width of sporangia and the average length of fungal pedicels (7). The organism was not obtained in pure culture and, therefore, the race was not determined.

AFLP DNA fingerprinting. Primer combinations used in AFLP distinguished between $P$. phaseoli and other species of Phytophthora tested but resulted in identical banding patterns for all races of $P$. phaseoli tested. Each lane was scored for the presence or absence of fragments between 80 and $212 \mathrm{bp}$. The PCR products of $>212 \mathrm{bp}$ were not scored because resolution was insufficient to discriminate between bands. A dendrogram produced from the AFLP data using simple matching coefficients revealed that similarity among isolates of $P$. phaseoli was 95 to $100 \%$ but between Phytophthora spp. was 50\% (Fig. 2).

\section{DISCUSSION}

The collection of isolates of $P$. phaseoli from 1994 through 2005 in Delaware and Maryland, and their race determination using cultivar differential testing, has identified two new races of $P$. phaseoli (E and F) and one isolate of $P$. phaseoli race B. Race $B$, which had not been collected in many years and was thought to be extinct, was isolated from home garden pole lima bean plants which are grown throughout the region and are susceptible to all known races of $P$. phaseoli (Table 3). Pole lima bean plantings are potential long-term hosts for older races of $P$. phaseoli because they lack resistance and frequently are planted in the same location year after year from saved seed.

Before 1995, race D of $P$. phaseoli was the dominant race in lima bean production in the mid-Atlantic region. In 1995, a new race of $P$. phaseoli designated $\mathrm{E}$ was isolated from lima bean in two fields near Milton, DE, 20 years after race D first had been detected. By 2000, race $\mathrm{E}$ had become dominant in the region (Table 2). In that same year, race $\mathrm{F}$ of $P$. phaseoli was isolated from lima bean in Frederica and Milford, DE. This was just 5 years after the emergence of race $E$. The rapid development of new races of $P$. phaseoli may indicate that the pathogen is able to adapt quickly to overcome resistance in new cultivars of lima bean.

Genetic variation among the three Phytophthora spp. is highly diverse. Based on the results of AFLP using primers EcoRI+AG and MseI+C, Phytophthora spp. separated into three clades. Divergence among isolates of $P$. phaseoli is very low, with 17 isolates being identical, and races were not distinguished. The wide genetic variation found between species of Phytophthora and the uniformity of this population suggests that this method is useful and suitable for detection of $P$. phaseoli.

Lima bean is a very important part of vegetable production in the mid-Atlantic region and the development of new races of $P$. phaseoli is a constant threat to the industry. New races of $P$. phaseoli have caused great losses to the vegetable-processing industry in Delaware and Maryland and threaten the viability of the vegetableprocessing industry in the region should this continue. Early detection of new races of $P$. phaseoli would permit the timely development of resistant lima bean cultivars by breeders to meet the industry's needs.

\section{ACKNOWLEDGMENTS}

We thank E. Kee for help in locating production lima bean fields in Delaware and the eastern shore of Maryland, J. D. Dominiak for assistance in the collection of Phytophthora isolates, and the Delaware Department of Agriculture for the financial support provided for a portion of this research.

\section{LITERATURE CITED}

1. Bao, J. R., Fravel, D. R., O'Neill, N. R., Lazarovits, G., and van Berkum, P. 2002. Genetic analysis of pathogenic and nonpathogenic Fusarium oxysporum from tomato plants. Can. J. Bot. 80:271-279.

2. Calvert, O. H., Williams, L. F., and Whitehead, M. D. 1960. Frozen lima bean agar for culture and storage of Phytophthora sojae. Phytopathology 50:136-137.

3. Camara, M., O'Neill, N., Dernoden, P., and Palm, M. 2000. Ophiosphaerella agrostis sp. nov. and its relationship to other species of Ophiosphaerella. Mycologia 92:317-325.

4. Caten, C. E., and Jinks, J. L. 1967. Spontaneous variability of single isolates of Phytophthora infestans. Can. J. Bot. 46:329-346.

5. Cox, R. S. 1954. Effects of temperature in the development of downy mildew of lima bean. Phytopathology 44:325-327.

6. Davidson, C. R., Carroll, R. B., Evans, T. A., Mulrooney, R. P., and Kim S. G. 2002. First report of Phytophthora capsici infecting lima bean (Phaseolus lunatus) in the mid-Atlantic region. Plant Dis. 86:1049.

7. Erwin, D. C., and Ribeiro, O. K. 1996. Phytophthora phaseoli Thaxter. In: Phytophthora Diseases Worldwide. American Phytopathological Society Press, St. Paul, MN.

8. Evans, T. A., Davidson, C. R., Dominiak, J. D., Mulrooney, R. P., Carroll R. B., and Antonius S. H. 2002. Two new races of Phytophthora phaseoli from lima bean in Delaware. Plant Dis. 86:813.

9. Evans, T. A., Mulrooney, R. P., Gregory, N. F. and Kee, E. 2007. Lima bean downy mildew: impact, etiology, and management strategies for Delaware and the Mid-Atlantic Region, U.S. Plant Dis. 91:128-135.

10. Flier, W. G., Grunwald, N. J., Kroon, L. P., Sturbaum, A. K., Vanden Bosch, T. B., GaraySerrano, E., Lozoya-Saldana, H., Fry, W. E., and Turkensteen, L. J. 2003. The population structure of Phytophthora infestans from the Toluca Valley of central Mexico suggests genetic differentiation between populations from cultivated potato and wild Solanum spp. Phytopathology 93:382-390.

11. Heuberger, J. W. 1948. The downy mildew disease of Henderson Bush lima bean. Trans. Penninsula Hortic. Soc. 40:111-114.

12. Hyre, R. A., and Cox, R. S. 1952. Further studies in the physiology of Phytophthora phaseoli. (Abstr.) Phytopathology 42:468.

13. Ivors, K. L., Hayden, K. J., Bonants, P. J., Rizzo, D. M., and Garbelotto, M. 2004. AFLP and phylogenetic analyses of North American and European populations of Phytophthora ramorum. Mycol. Res. 108:378-392.

14. Lin, J. J., and Kuo, J. 1995. A novel PCRbased assay for plant and bacterial DNA fingerprinting. Focus 17:66-70.

15. Kaminski, J. E., Dernoeden, P. H., Mischeke, S., and O'Neill, N. R. 2006. Genetic diversity among Ophiosphaerella strains causing dead spot in creeping bentgrass. Plant Dis. 90:146154.

16. Kee, W. E. 1986. Lima beans show steady success in Delaware. Am. Veg. Grow. 34:78-79.

17. Kee, W. E. Glancey, J. L., and Wooten, T. L. 1997. The lima bean: a vegetable crop for processing. HortTechnology 7:119-128.

18. Kirk, P. M., Cannon, P. F., David, J. C., and Stapler, J. A. 2001. Dictionary of the Fungi, 9th ed. CABI Publishers, Wallingford, Oxon, UK

19. Martin, F. N., and Tooley, P. W. 2003. Phylogenetic relationships among Phytophthora species inferred from sequence analysis of mitochondrially encoded cytochrome oxidase I and II genes. Mycologia 95:269-284.20.

20. O'Neill, N. R., van Berkum, P., Lin, J. J., Kuo, J., Ude, G. N., Kenworthy, W., and Saunders, J. A. 1997. Application of amplified restriction fragment length polymorphism for genetic characterization of Colletotrichum pathogens of alfalfa. Phytopathology 87:745-750.

21. Scuse, M. T., and Cadwallader, C. L. 2005. Delaware agricultural statistics summary for 2004. Delaware Department of Agriculture, Dover.

22. Smith, C. O. 1904. Mildew of lima bean. Del. Agric. Exp. Stn. Bull. 63:23-28.

23. Stakman, E. C., and Levine, M. N. 1938 Analytical key for the identification of physiologic races of Puccinia graminis tritici. Div. Cereal Crops Dis. U.S. Dep. Agric. Minn. Agric. Exp. Stn.

24. Stakman, E. C., Levine, M. N., and Loegering, W. Q. 1944. Identification of physiologic races of Puccinia graminis tritici. U. S. Dep. Agric. Bur. Entomol. Plant Quarant. E-617.

25. Stakman, E. C., and Piemeisel, F. J. 1917. A new strain of Puccinia graminis. (Abstr.) Phytopathology 7:73.

26. Stavely, J. R. 1991. Lima bean (Phaseolus lunatus L.) development at Beltsville. Bean Improv. Coop. Annu. Rep. 34:155-156.

27. Thaxter, R. 1889. A new American Phytophthora. Bot. Gaz. 14:273-274.

28. Thomas, C. A., and Blount, V. L. 1976. Race D of Phytophthora phaseoli. Plant Dis. Rep. 60:308.

29. Tooley, P. W., O’Neill, N. R., Goley, E. D., and Carras, M. M. 2000. Assessment of diversity in Claviceps africana and other Claviceps species by RAM and AFLP analysis. Phytopathology 90:1126-1130.

30. Tuite, J. 1969. Plant Pathological Methods, Fungi and Bacteria. Burgess Publishing Co., Minneapolis, MN.

31. Vigi, G., Uddin, W., O'Neill, N. R., Mischke, S., and Saunders, J. A. 2004. Genetic diversity of Sclerotinia homoeocarpa isolates from turfgrasses from various regions in North America. Plant Dis. 88:1269-1276

32. Vos, P., Hogers, R., Bleeker, M., Reijans, M., van de Lee, T., Hornes, M., Frijters, A., Pot, J., Peleman, J., Kuiper, M., and Zabeau, M. 1995. AFLP: a new technique for DNA fingerprinting. Nucleic Acids Res. 23:4407-4414.

33. Wester, R.E. 1968. New lima beans resistant to "B" strain of Phytophthora phaseoli. Plant Dis. Rep. 52:563-564.

34. Wester, R. E. 1970. A new race of downy mildew on lima beans. Phytopathology 60:1856.

35. Wester, R. E., and Jorgensen, H. 1959. A new race of Phytophthora phaseoli from lima beans. Plant Dis. Rep. 43:184-186.

36. Walker, J. C. 1952. Downy mildew of lima bean. In: Diseases of Vegetable Crops. McGraw-Hill, New York. 